\title{
EFEKTIVITAS PENERAPAN GOOD CORPORATE GOVERNANCE (GCG) DALAM UPAYA PENCEGAHAN TINDAK PIDANA KORUPSI DI PT KERETA API INDONESIA (PERSERO) Oleh: Rizqi Yurice Prastika ${ }^{1}$
}

\begin{abstract}
As a result of the poor corporate governance, many corruption cases have occurred in state-owned and private companies. Effective GCG implementation is a step to prevent, hinder and make it difficult for someone to commit acts of corruption because GCG has principles such as transparency, accountability, responsibility, independence and fairness. This study aims to determine and analyze the effectiveness of GCG implementation an effort to prevent corruption in PT Kereta Api Indonesia (Persero) and to find out and analyze the obstacles faced in implementing GCG at PT Kereta Api Indonesia (Persero). This research was conducted at PT Kereta Api Indonesia (Persero).

Based on the results of research from the internal audit data in the last three years, there was no corruption found involving all components of the company. Implementation of GCG so far is still effective in preventing corruption. Legal remedies made as a last resort still have a deterrent effect, this is due to being followed by severe sanctions. In addition to this to prevent corruption PT Kereta Api Indonesia (Persero) has implemented a whistleblowing system (WBS), Gratuity Control, Conflict of Interest and Management of State Operator Assets Reports (LHKPN).

Based on the results of the analysis it can be concluded that GCG implementation in an effort to prevent corruption in PT Kereta Api Indonesia (Persero) based on the results of the research has been effective, this has been proven by the fact that in the past three years there has been no corruption involving all elements of the company. The unity of the system consisting of substance, structure and legal culture is able to contribute maximally to the running of the GCG system at PT Kereta Api Indonesia (Persero) and the constraints faced in implementing GCG can be said to be non-existent because GCG has become a system that runs and reaches all company elements to create better corporate governance from year to year. Keywords: Good Corporate Governance (GCG), Prevention, Corruption
\end{abstract}

\begin{abstract}
ABSTRAK
Akibat dari buruknya tata kelola perusahaan menyebabkan banyak terjadinya tindak pidana korupsi di perusahaan BUMN maupun swasta. Penerapan GCG secara efektif merupakan sebagai langkah mencegah, menghambat dan mempersulit seseorang melakukan tindakan korupsi dikarenakan GCGmemiliki prinsip-prinsip seperti Transparancy, Accountability, Responsibility, Independency dan Fairness. Penelitian ini bertujuan untuk mengetahui dan menganalisis efektivitas penerapan GCG dalam upaya pencegahan tindak pidana korupsi di PT Kereta Api Indonesia (Persero) dan untuk mengetahui dan menganalisis kendala yang dihadapi dalam penerapan GCG di PT Kereta Api Indonesia (Persero). Penelitian ini dilakukan di PT Kereta Api Indonesia (Persero).

Berdasarkan hasil penelitian dari data hasil audit internal tiga tahun terakhir tidak ditemukan tindak pidana korupsi yang melibatkan seluruh komponen perusahaan. Implementasi GCG sampai sejauh ini masih efektif untuk mencegah terjadinya tindak pidana korupsi. Upaya hukum yang dijadikan upaya terakhir tetap memberikan efek jera, hal tersebut dikarenakan diikuti dengan pemberian sanksi yang berat. Selain hal itu, untuk mencegah terjadinya korupsi PT Kereta Api Indonesia (Persero) telah menerapkan
\end{abstract}

\footnotetext{
${ }^{1}$ Bekerja BUMN, Kabupaten Banyumas
} 
whistleblowing System (WBS), Pengendalian Gratifikasi, Benturan Kepentingan (Conflict of Interest) dan Pengelolaan Laporan Harta Kekayaan Penyelenggara Negara (LHKPN).

Berdasarkan hasil analisis dapat disimpulkan bahwa Penerapan GCG dalam upaya pencegahan tindak pidana korupsi di PT Kereta Api Indonesia (Persero) berdasarkan hasil penelitian sudah efektif, hal tersebut dibuktikan dengan selama tiga tahun terakhir tidak ada tindak pidana korupsi yang melibatkan seluruh elemen perusahaan. Kesatuan sistem yang terdiri atas substance, structure dan legal culture mampu memberikan kontribusi maksimal terhadap jalannya sistem GCG di PT Kereta Api Indonesia (Persero) dan kendala yang dihadapi dalam menerapkan GCG dapat dikatakan tidak ada dikarenakan GCG sudah menjadi sebuah sistem yang berjalan dan menjangkau ke seluruh elemen perusahaan untuk menciptakan tata kelola perusahaan yang lebih baik dari tahun ke tahun.

Kata Kunci : Good Corporate Governance (GCG), Pencegahan, Korupsi

\section{A. Pendahuluan}

Krisis ekonomi telah menjadi landasan untuk melakukan refleksi kritis dan auto kritik atas kebijakan pembangunan yang selama ini dilakukan. Introspeksi dan refleksi diri merupakan suatu yang sangat berharga bagi kemajuan bangsa. Salah satu penyebab krisis adalah standar tata kelola yang rendah, baik dalam sektor ekonomi publik maupun korporat. ${ }^{2}$ Tata kelola perusahaan atau dikenal dengan Good Corporate Governance, menjadi isu penting bahkan menjadi isu yang sangat menarik dari waktu ke waktu, khususnya mulai mengemuka pada tahun 1998 ketika Indonesia mengalami krisis yang berkepanjangan karena lemahnya praktik Good Corporate Governance.

Secara umum $\begin{array}{r}\text { industri } \\ \text { memerlukan }\end{array}$
$\begin{aligned} & \text { perkeretaapian } \\ & \text { pengelolaan yang lebih baik, lebih } \\ & \text { komersial dan responsif. Sebagai }\end{aligned}$

2 Muhammad Shidqon Prabowo, 2004. Dasar - Dasar Good Corporate Governance, UII Press Yogyakarta, Yogyakarta. Hal. 1. konsekuensinya industri perkertaapian di banyak negara memerlukan reformasi untuk memperbaiki performa operasional dan keuangan. Beberapa permasalahan yang pernah dihadapi di industri perkeretaapian di dunia sebagai berikut :

a. Defisit keuangan yang kronis;

b. Pertumbuhan subsidi operasional;

c. Sistem harga yang tidak berubah menyesuaikan biaya;

d. Biaya operasional terlalu tinggi;

e. Efisiensi operasional yang rendah;

f. Manajemen lemah dan efisiensi teknis yang rendah;

g. Produktivitas tenaga kerja rendah;

h. Rendahnya kualitas jasa pelayanan;

i. Buruknya perawatan aset;

j. Kurangnya dana untuk melakukan investasi infrastruktur transportasi;

k. Kurangnya partisipasi pihak swasta. $^{3}$

Akibat dari buruknya tata kelola perusahaan menyebabkan banyak terjadinya tindak pidana korupsi di

3 Toto Pranoto dkk, 2015. KAl Recipe Perjalanan Transformasi Kereta Api Indonesia, Lembaga Management Fakultas Ekonomi dan Bisnis Universitas Indonesia, Jakarta. Hal. 3. 
perusahaan BUMN maupun swasta. Korupsi saat ini merupakan permasalahan bukan hanya bagi Indonesia namun juga bagi masyarakat internasional. Bagi masyarakat internasional perang terhadap masalah korupsi ini antara lain terlihat dari ketentuan $O E C D$, mengenai Convention on Combating Bribery of Foreign Public Officials in International Business transaction, yang bertujuan untuk mencegah dan memberantas penyuapan terhadap pejabat publik asing dalam hubungannya dengan bisnis internasional. Demikian pula setiap tahun Political and Economic Risk Consultancy (PERC), selalu mengumumkan hasil surveinya mengenai peringkat korupsi negaranegara di dunia, dimana sama-sama kita ketahui bahwa Indonesia merupakan salah satu negara yang masuk dalam pemeringkatan tingkat korupsinya. ${ }^{4}$ Selain itu Transparancy International merilis indeks persepsi korupsi negaranegara di dunia untuk tahun 2017 dan Indonesia berada di peringkat ke-96 dari 180 negara. $^{5}$

Berdasarkan data KPK, jumlah perkara korupsi yang melibatkan BUMN/BUMD mencapai 11 kasus pada

\footnotetext{
${ }^{4}$ Sjahruddin Rasul, 2009. Penerapan Good Governance di Indonesia Dalam Upaya Pencegahan Tindak Pidana Korupsi. Mimbar Hukum. Vol. 21 (3) : 542

5 https://news.detik.com/berita/d3879592/indeks-persepsi-korupsi-2017indonesia-peringkat-ke-96 diakses 30 Oktober 2018.
}

2016. Jumlah tersebut meningkat signifikan dibandingkan tahun 2015 yang hanya 5 kasus. Pada tahun-tahun sebelumnya pun, jumlah perkara yang melibatkan BUMN/BUMD paling banyak 7 kasus, yakni pada 2010. Indikasi lainnya terlihat dari Laporan Transaksi Keuangan Mencurigakan (LTKM) yang diterima Pusat Pelaporan dan Analisis Transaksi Keuangan (PPATK). Selama Januari - Februari 2017, PPATK menerima LTKM yang dilakukan pegawai atau pejabat BUMN/BUMD sebanyak 159 laporan. Jumlah tersebut meningkat signifikan dibandingkan periode yang sama tahun 2016 yaitu sebanyak 89 laporan. ${ }^{6}$

Penerapan Good Corporate Governance di Indonesia (khususnya perusahaan BUMN) dimulai dengan diterbitkannya Keputusan Menteri Negara Penanaman Modal dan Pembinaan BUMN melalui SK. No. Keputusan 23/M-PM.PBUMN/2000 tentang Pengembangan Praktik Good Corporate Governance dalam perusahaan perseroan (Persero). Berdasarkan Pasal 2 ayat (1) Peraturan Menteri Negara Badan Usaha Milik Negara Nomor : PER-01 /MBU/2011 Tentang Penerapan Tata Kelola Perusahaan Yang Baik (Good Corporate Governance) Pada Badan Usaha Milik Negara menyatakan bahwa BUMN wajib

\footnotetext{
${ }^{6}$ https://bisniskeuangan.kompas.com/read/20 17/04/15/070000926/korupsi.bumn.yang.mak in.menggila. diakses 30 Oktober 2018.
} 
99 | Jurnal Idea Hukum

Vol. $6 \mathrm{No} .1 \mathrm{M}$ a re t 2020

Magister Hukum Universitas Jenderal Soedirman

menerapkan GCG secara konsisten dan berkelanjutan dengan berpedoman pada Peraturan Menteri ini dengan tetap memperhatikan ketentuan, dan norma yang berlaku serta anggaran dasar BUMN.

Sebagaimana penelitian yang telah dilakukan oleh KPK dengan judul Studi Implementasi Good Corporate Governance di Sektor Swasta, BUMN dan $\mathrm{BUMD}^{7}$, didalam penelitian tersebut disebutkan bahwa salah satu tujuan dari implementasi GCG pada sektor usaha adalah agar tercipta kondisi usaha yang bersih dari praktek-praktek korupsi, baik secara internal perusahaan maupun dalam kaitannya dengan perusahaan atau lembaga lain. Oleh karena itu, perlu didalami bagaimana upaya-upaya yang dilakukan oleh perusahaan dalam mencegah tindakan korupsi. ${ }^{8}$

Didalam sebuah perusahaan yang sudah menerapkan Good Corporate Governance, tetapi masih saja dijumpai kasus tindak pidana korupsi yang menjerat dua mantan petinggi PT Kereta Api Indonesia (Persero). Berdasarkan putusan Mahkamah Agung Nomor 1401K/PID.SUS/2014 Tahun 2015 dengan terdakwa Ronny Wahyudi

${ }^{7}$ https://acch.kpk.go.id/id/component/bdthem es shortcodes/?view=download\&id=5fa0dd6 9313917c23f775345219cda hubungan penerapan $\mathrm{gcg}$ dengan pencegahan tindak pidana korupsi diakses 2 September 2018. 8 Ibid., Hal. 14. (mantan Direktur Utama) $)^{9}$ dan Putusan Mahkamah Agung Nomor 1553K/PID.SUS/2013 Tahun 2014 dengan terdakwa Achmad Kuncoro (mantan Direktur Keuangan) ${ }^{10}$ mereka dinyatakan bersalah dalam korupsi dana investasi PT Kereta Api Indonesia (Persero) dengan PT Optima Kharya Capital Management yang mengakibatkan kerugian negara $\mathrm{Rp} 100$ Miliar. Selain kasus tersebut, Yayat Rustandi (mantan Executive Vice President Daop 6 Yogyakarta) dalam Putusan PN Yogyakarta Nomor 02/PID.SUS/2014/P.TPIKOR.YK Tahun 2014 divonis dengan pidana penjara selama 1 (satu) tahun dan denda sebesar Rp 50.000.000,00 ${ }^{11}$ yaitu terkait proyek Pekerjaan Revitalisasi Flow Penumpang dan Penataan Stasiun Lempuyangan yang menyebabkan kerugian negara sebesar Rp 64,9 juta. ${ }^{12}$

Masalah lain yaitu setidaknya tercatat 38 persen dari total aset PT Kereta Api Indonesia (Persero) seluas 320 juta meter persegi diketahui belum berserfikat. Menurut KPK dalam Forum

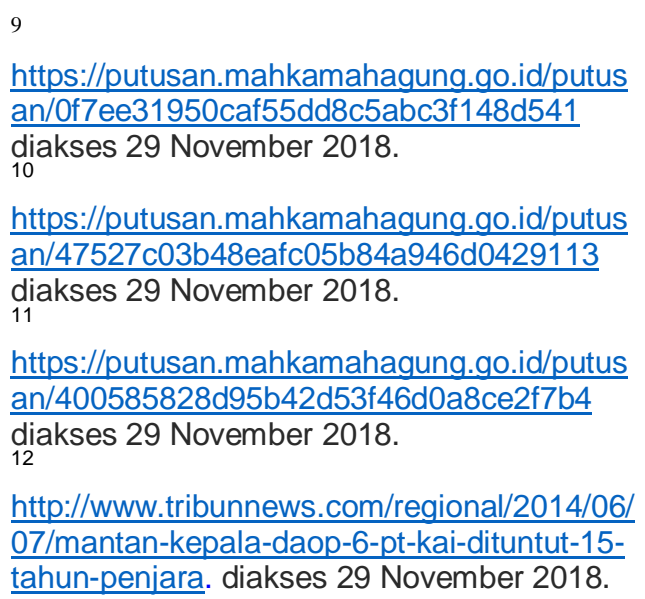

http://www.tribunnews.com/regional/2014/06/ 07/mantan-kepala-daop-6-pt-kai-dituntut-15tahun-penjara. diakses 29 November 2018. 


\begin{tabular}{|c|}
\hline $\begin{array}{l}\text { Group Discussion } \\
\text { Pengenai } \\
\text { Pemanfaatan Aset bersama KPK, } \\
\text { kondisi tersebut jangan sampai } \\
\text { dibiarkan, karena jika aset dilepas } \\
\text { berarti kerugian bagi negara dan } \\
\text { berpotensi korupsi. }{ }^{13} \text { Selain hal tersebut } \\
\text { hingga saat ini dengan belum } \\
\text { diterapkannya SNI ISO } 37001: 2016 \\
\text { Sistem Manajemen Anti Penyuapan } \\
\text { maka praktis hanya Good Corporate } \\
\text { Governance (GCG) yang dapat } \\
\text { mencegah terjadinya tindak pidana } \\
\text { korupsi di PT Kereta Api Indonesia } \\
\text { (Persero). }{ }^{14}\end{array}$ \\
\hline
\end{tabular}

\section{B. Metode Penelitian}

Tipe Penelitian adalah Deskriptif Analisis, dengan metode pendekatan Yuridis Sosiologis. Sumber Data yang digunakan Data Primer dan Data Sekunder. Metode Pengumpulan Data:

a. Data Primer diperoleh dengan melalui wawancara terhadap sumber pertama.

b. Data Sekunder diperoleh dengan melakukan inventarisasi peraturanperaturan, ketentuanketentuan dan literature yang memberikan pengaturan dan penjelasan

13

https://www.liputan6.com/news/read/305832 0/kpk-beri-warning-pt-kai-soal-kepemilikanaset diakses 28 Agustus 2018.

${ }^{14}$ Berdasarkan Hasil Penelitian Awal di PT Kereta Api Indonesia (Persero) Pada Tanggal 30 November 2018. yang berhubungan dengan

pokok permasalahan.

Hasil penelitian disajikan dalam bentuk teks naratif yang disusun secara sistematis, dan penelitian dianalisis dengan metode kualitatif.

\section{Hasil Penelitian dan Pembahasan}

1. Efektivitas penerapan Good Corporate Governance (GCG) dalam upaya pencegahan tindak pidana korupsi di PT Kereta Api Indonesia (Persero)

Secara konseptual di negara berkembang, pemikiran bahwa korupsi ini bagian dari kekuasaan bahkan bagian dari sistem itu sendiri menjadi tidak diragukan, karenanya ada yang berpendapat bahwa penanggulangan yang terpadu adalah dengan memperbaiki sistem yang ada. ${ }^{15}$ Hal tersebut juga dilakukan oleh PT Kereta Api Indonesia (Persero) yaitu dengan menerapkan Good Corporate Governance sebagai sebuah sistem yang diharapkan mampu untuk mencegah terjadinya tindak pidana korupsi di PT Kereta Api Indonesia (Persero). Untuk memahami persoalan yang berkaitan dengan hukum secara lebih baik, maka hukum hendaknya

\footnotetext{
${ }^{15}$ Indriyanto Seno Adji, 2015. Komisi Pemberantasan Korupsi dan Penegakan Hukum, Diadit Media, Jakarta. Hal. 12.
} 
Vol. $6 \mathrm{No} .1 \mathrm{M}$ a re t 2020

Magister Hukum Universitas Jenderal Soedirm a n

dilihat sebagai suatu sistem. Pengertian dasar yang terkandung dalam sistem tersebut meliputi :

1) Sistem itu selalu berorientasi pada suatu tujuan

2) Keseluruhan adalah lebih dari sekedar jumlah dan bagian-bagiannya

3) Sistem itu selalu berinteraksi dengan sistem yang lebih besar yaitu lingkungannya, dan

4) Bekerjanya bagian-bagian dari sistem itu menciptakan sesuatu yang berharga. ${ }^{16}$ Hukum bergerak diantara

dua dunia yang berbeda, baik dunia nilai maupun dunia sehari-hari (realitas sosial). Akibatnya, sering terjadi ketegangan disaat hukum itu diterapkan. Ketika hukum yang sarat dengan nilai-nilai itu hendak diwujudkan, maka ia harus berhadapan dengan berbagai macam faktor yang mempengaruhi dari lingkungan sosialnya. ${ }^{17}$ Bicara soal hukum sebagai suatu sistem, Lawrence M. Friedman mengemukakan adanya komponen-komponen yang terkandung dalam hukum tersebut meliputi structure, substance dan legal culture. Oleh karena untuk bisa memahami efektivitas penerapan Good Corporate Governance (GCG) dalam upaya pencegahan tindak pidana korupsi

${ }^{16}$ Satjipto Rahardjo, 2000. IImu Hukum, PT. Citra Aditya Bakti, Bandung. Hal. 48-49.

${ }^{17}$ Esmi Warassih, 2005. Pranata Hukum Sebagai Sebuah Telaah Sosiologis. PT Suryandaru Utama, Semarang. Hal. 80-81.

\author{
di PT Kereta Api Indonesia \\ (Persero) perlu dianalisis satu \\ persatu dari ketiga komponen \\ tersebut.
}

a. Substance

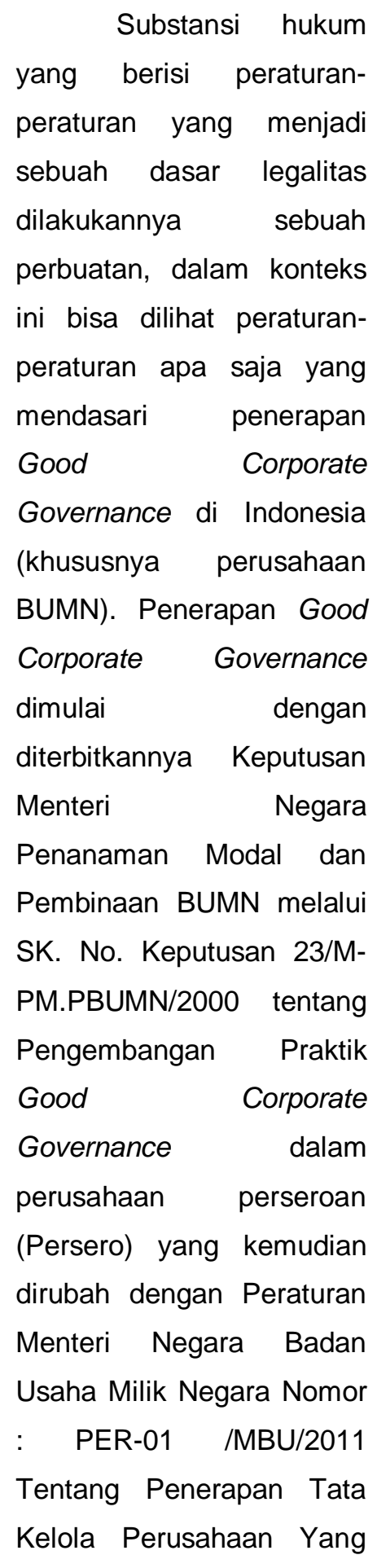




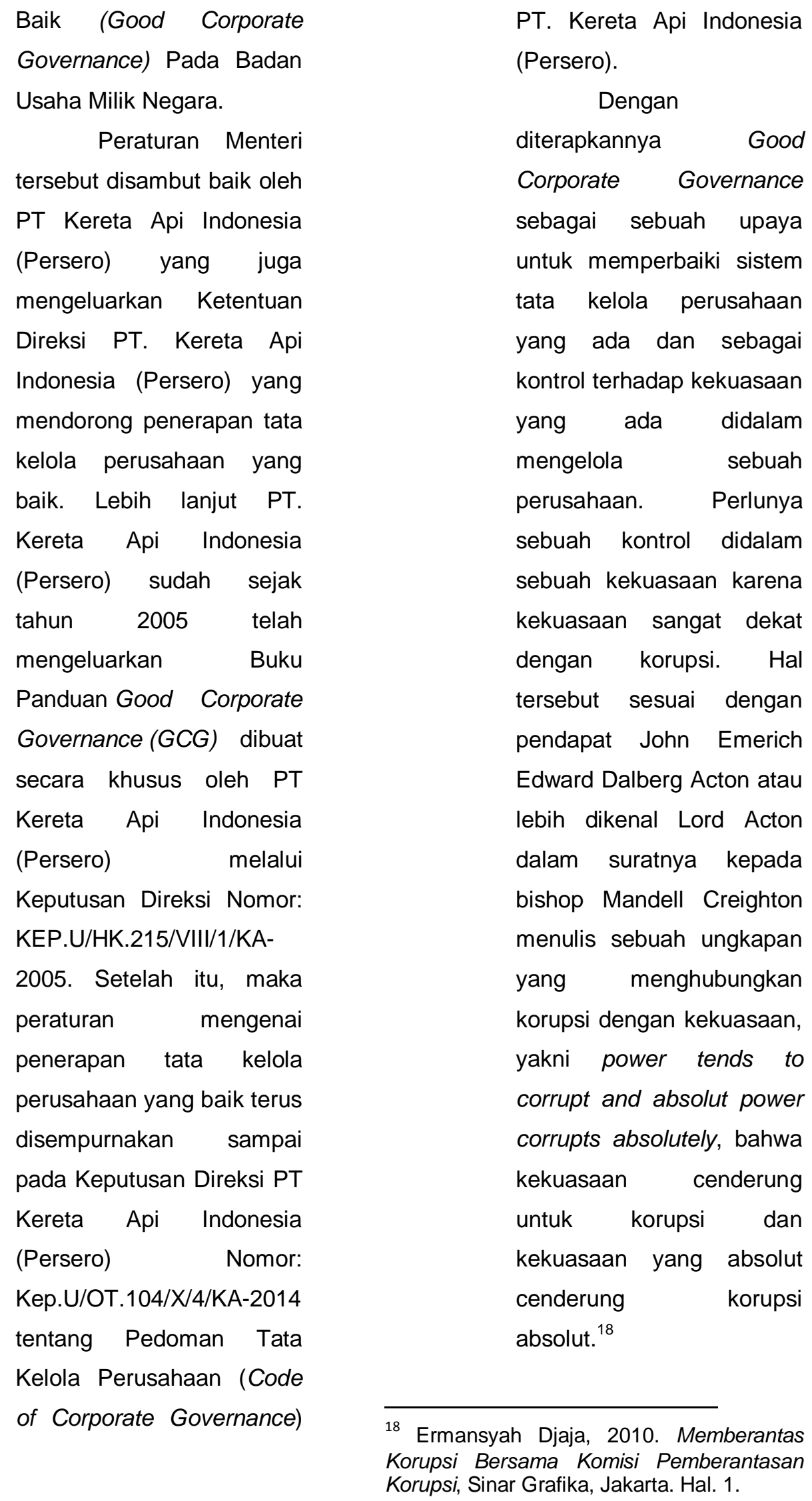


Vol. $6 \mathrm{No} .1 \mathrm{M}$ a re t 2020

Magister Hukum Universitas Jenderal Soedirm a n

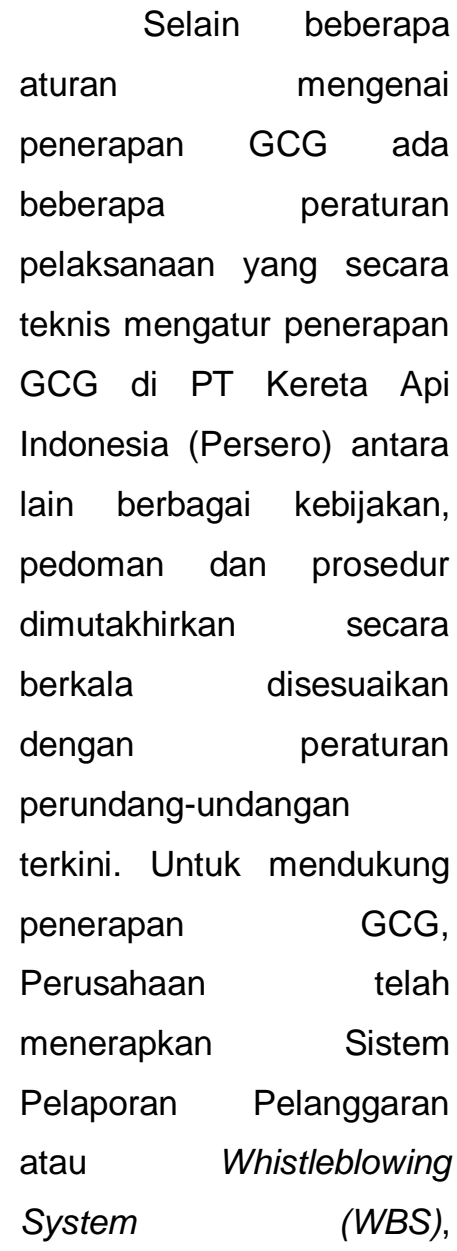

Pengendalian Gratifikasi, Benturan Kepentingan (Conflict of Interest) dan Pengelolaan Laporan Harta Kekayaan Penyelenggara Negara (LHKPN). Direksi telah menetapkan dalam SK Nomor KEP.U/KP.402/V/1/KA2016 tanggal 9 Mei 2016 tentang Tata Cara Pelaporan, Pengumuman dan Pengelolaan Laporan Harta Kekayaan Penyelenggara Negara, bahwa penyampaian
LHKPN harus dilakukan sampai tingkat Manager atau 3 tingkat di bawah Direksi.

Jika dilihat dari berbagai peraturan yang ada, maka dapat dikatakan segala sesuatu yang berkaitan dengan substance (substansi) sudah cukup lengkap untuk mewujudkan Good Corporate Governance yang efektif. Namun selengkap apapun substansi atau peraturan yang ada, tanpa didukung dengan structure dan legal culture yang baik tidak akan mungkin menjadikan peraturan tersebut berjalan efektif.

b. Structure

Berdasarkan hasil penelitian di PT Kereta Api Indonesia (Persero) struktur yang memiliki tanggung jawab terhadap penerapan GCG yaitu Vice President (VP) Quality Assurance and GCG yang berada dibawah

Sektretaris Perusahaan (Corporate Secretary). Struktur organisasi Sekretaris Perusahaan sesuai Keputusan Direksi Nomor: KEP.U/KO.104/ 
$\mathrm{VI} / 1 / \mathrm{KA}-2016$ Tanggal 9

Juni 2016 Tentang Struktur

Organisasi dan Tata

Laksana Sekretariat

Perusahaan.

Jika dilihat dari

beberapa kegiatan yang

berkaitan dengan

implementasi GCG seperti

melakukan penyempurnaan

kebijakan GCG, sosialisasi

dan internalisasi GCG ke

unit-unit usaha (Daop,

Divre, Balai Yasa, dan

Kantor Pusat),

meningkatkan kepatuhan

pelaporan LHKPN serta

melaksanakan kegiatan-

kegiatan terkait pendidikan

anti korupsi tentunya

membuktikan bahwa GCG

di PT Kereta Api Indonesia

bukan hanya jargon semata

namun wujud nyata dari

implementasi tersebut ada

dan berjalan.

Dari

hasil

monitoring Unit QA \& CGC

sebagai koordinator

pengelolaan LHKPN,

jumlah pelaporan melalui

formulir e-Filling LHKPN

hingga akhir tahun 2017

telah mencapai 886 dari

893 wajib lapor atau

sebesar 99,2\%. Dengan

pengisian LHKPN tersebut tentunya sebagai sebuah

awal untuk mencegah

terjadinya tindak pidana

korupsi di PT Kereta Api

Indonesia (Persero) dan

melaporkan LHKPN

merupakan sebuah wujud

komitmen menerapkan

GCG yang selaras dengan

salah satu prinsip GCG

yaitu Transparansi. PT

Kereta Api Indonesia

(Persero) juga meraih

penghargaan dalam ajang

International Business

Integrity Conference 2017

yang diselenggarakan oleh

Komisi Pemberantasan

Korupsi (KPK) dalam

kategori Lembaga dengan

Tingkat Kepatuhan LHKPN

Terbaik Tahun 2017 (The

Best LHKPN Compliance

Institution in 2017).

Dengan demikian, paling tidak terdapat 6 alasan perlunya sektor swasta menangani kasus korupsi secara serius, baik tindak penyuapan, pencucian uang, atau tindak korupsi lainnya.

a) Pertama, bisnis dapat berkembang jika memiliki akses ke pasar internasional, sehingga untuk mendapatkan 


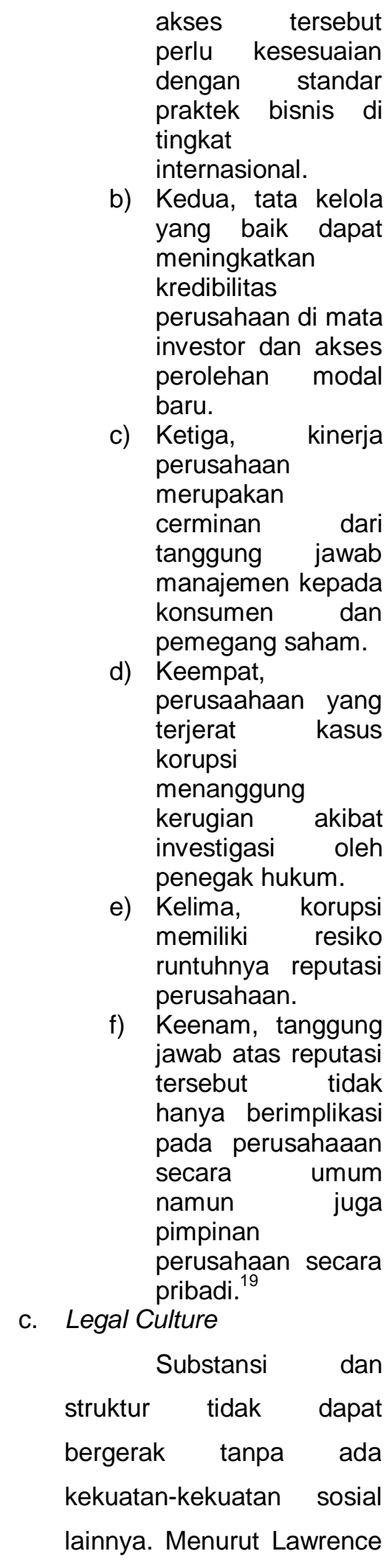

${ }^{19}$ Ibid.,
M. Friedman bahwa ada kekuatan lainnya selain substansi dan struktur dalam menggerakkan hukum. Menurut Lawrence M. Friedman, subsistem yang terakhir adalah kultur hukum atau budaya hukum bahwa the legal culture, system - their beliefs, values, ideas and expectasions. (kultur hukum merupakan sikap manusia terhadap hukum, sistem hukumkepercayaaan, nilai, pemikiran, serta harapannya). Legal culture refers then, two those part of general culture-customs, opinions, ways of doing and thinking that bend social forces to war door away from the law and inparticullar ways. (kultur hukum adalah suasana pikiran sosial dan kekuatan sosial yang menentukan bagaimana hukum digunakan, dihindari, atau disalahgunakan).

Friedman

menyatakan bahwa tegaknya peraturanperaturan hukum tergantung pada budaya hukum masyarakatnya. 
Budaya hukum masyarakat tergantung kepada budaya hukum anggotaanggotanya yang dipengaruhi oleh latar belakang pendidikan, lingkungan, budaya, posisi atau kedudukan, bahkan kepentingan-kepentingan.

Menurut Friedman, tanpa dukungan dari budaya hukum, maka hukum itu tidak akan pernah jalan. ${ }^{20}$ Konsep inilah yang diadopsi oleh PT Kereta Api Indonesia (Persero) dalam menerapkan GCG secara konsisten dan menerapkan nilai-nilai budaya perusahaan. Salah satu nilai didalam 5 nilai utama didalam PT Kereta Api Indonesia (Persero) yaitu Integritas. Integritas disini dimaknai sebagai bertindak konsisten sesuai dengan nilai-nilai kebijakan organisasi dan kode etik perusahaan. Memiliki pemahaman dan keinginan untuk menyesuaikan diri dengan kebijakan dan etika tersebut dan bertindak secara konsisten walaupun sulit untuk melakukannya

${ }^{20}$ Lawrence M. Friedman, 1984. American Law, W. Norton \& Co, London. Hal. 8. (termasuk berprilaku jujur dan dapat dipercaya).

Dengan nilai-nilai yang ada dan ditanamkan kedalam setiap insan kereta api merupakan sebuah langkah yang tepat dalam mengoptimalkan bagian dari sebuah sistem hukum yang terpenting ini. Berdasarkan data 3 tahun terakhir diungkapkan bahwa sistem tata kelola perusahaan yang baik yang selama ini dijalankan secara menyeluruh dan konsisten oleh PT Kereta Api Indonesia (Persero) memberikan dampak yang positif yaitu dibuktikan dengan menurunnya jumlah pelanggaran yang tergolong (fraud) maupun yang tergolong sebagai tindak pidana korupsi. Selain hal tersebut penerapan GCG yang dijalankan secara konsisten dan transparan dapat mengurangi tingkat kebocoran pendapatan dan penggelembungan pembiayaan. $^{21}$

Dengan penerapan nilai-nilai tersebut sebagai sumber dari penerapan

${ }^{21}$ Toto Pranoto dkk, op., cit. Hal. 21. 
$\mathrm{V}$ ol. $6 \mathrm{No} .1 \mathrm{M}$ a re t 2020

Magister Hukum Universitas Jenderal Soedirm a n

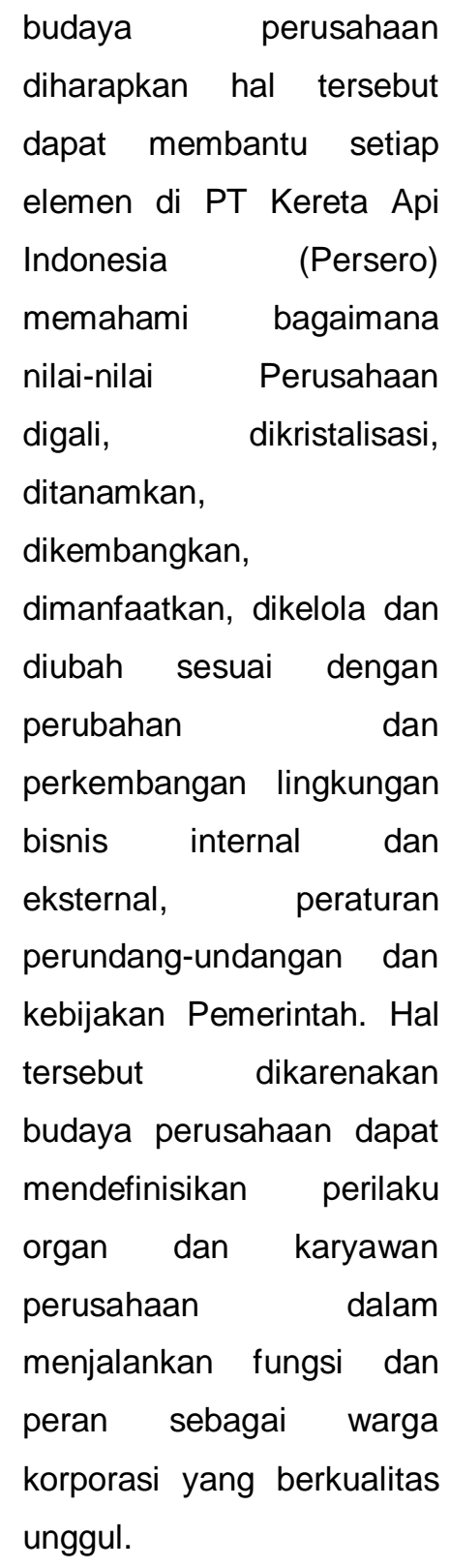

Dengan penerapan nilai-nilai ini juga berhasil merubah pola lama sebagai perusahaan yang product oriented menjadi perusahaan yang customer oriented sehingga pelayanan terhadap pengguna jasa menjadi lebih baik. Tugas terberat bagi PT Kereta Api Indonesia (Persero) adalah terus menjaga konsistensi pelayanan prima dari waktu ke waktu, dari stasiun ke stasiun, dari kereta ke kereta dan dari purchase ke purchase selanjutnya. Hal ini karena kereta api masuk dalam kategori jasa yang high contract yaitu pelanggan ikut serta atau pelanggan juga berinteraksi langsung dengan frontliner serta pelanggan lain saat mengkonsumsi jasa yang disediakan oleh PT Kereta Api Indonesia (Persero). Oleh karena itu untuk menghadapi tugas berat tersebut perlu ditumbuhkan kepercayaan, kebanggaan, rasa memiliki terhadap perusahaan yang terbentuk nyata dalam perubahan peraturan, struktur, recruitment system, staffing system, sistem penggajian, reward and punishment system, merit system, training and development, aroma like and dislike serta unfairness ditinggalkan, bahkan dengan benchmarking ke mancanegara. 


$\begin{array}{lr}\text { Hal } & \text { terpenting } \\ \text { tentunya dari } & \text { berbagai } \\ \text { perubahan yang terjadi dari } & \\ \text { mulai } & \text { diberlakukannya } \\ \text { Good } & \text { Corporate }\end{array}$

Governance di PT Kereta Api Indonesia (Persero) yaitu berdasarkan hasil penelitian di Unit Internal Audit bahwa selama 3 tahun terkhir tidak terjadi penyalahgunaan keuangan maupun terjadinya tindak pidana korupsi. Adanya temuan didalam audit internal dapat diselesaikan melalui mekanisme penyelesaian internal, karena upaya hukum merupakan upaya yang dilakukan sebagai upaya terakhir (ultimum remmidium).

2. Kendala yang dihadapi dalam penerapan Good Corporate Governance (GCG) di PT Kereta Api Indonesia (Persero)

Upaya pembangunan program antikorupsi korporasi di Indonesia masih tergolong rendah. Hasil survei Transparency International Indonesia dalam Transparency in Corporate Reporting 2017, mengungkapkan dari 100 perusahaan besar (Fortune Top 100) di Indonesia, $68 \%$ pimpinan perusahaan tidak memiliki komitmen antikorupsi, 73\% tidak memiliki peraturan yang tegas melarang praktik uang pelicin, 39\% tidak memiliki kebijakan mengenai manajemen pemberian (gratifikasi, hadiah, menjamu tamu, dan pengeluaran), 60\% tidak memiliki kebijakan tentang kontribusi politik, $71 \%$ tidak memberlakukan program antikorupsi kepada pihak lain (supplier, agen, penghubung, dll.), $67 \%$ tidak ada program antikorupsi pada pemasok, $74 \%$ tidak memiliki pelatihan antikorupsi. Hanya $57 \%$ yang memiliki sistem pengaduan yang menjamin kerahasiaan pelapor dan $40 \%$ korporasi yang memungkinkan pelapor tanpa risiko retaliasi. Mayoritas perusahaan tidak melakukan upaya untuk membuat pelaporan program antikorupsi yang menilai efektivitas program antikorupsi. Hal ini menunjukkan penerapan program antikorupsi pada perusahaan besar di Indonesia yang ideal masih menjadi tantangan besar bagi korporasi di Indonesia. $^{22}$

Hal tersebut tentu disadari oleh PT Kereta Api Indonesia (Persero) sebagai salah satu BUMN yang mantan direkturnya pernah terjerat kasus korupsi dimasa lalu tentu ingin

${ }^{22}$ Dwi Siska Susanti, Nadia Sarah, Nurindah Hilimi, 2018. Korporasi Indonesia Melawan Korupsi: Strategi Pencegahan, Integritas, Vol. 4 (2) : 224 
Vol. $6 \mathrm{No} .1 \mathrm{M}$ a re t 2020

Magister Hukum Universitas Jenderal Soedirm a n

memberbaiki tata kelola perusahaan agar hal tersebut tidak terjadi lagi dimasa mendatang. Dalam upaya perbaikan yang terus dilakukan untuk mendukung pencegahan tindak pidana korupsi dengan Good Corporate Governance, PT Kereta Api Indonesia (Persero) telah menerapkan Sistem Pelaporan Pelanggaran atau whistleblowing System (WBS), Pengendalian Gratifikasi, Benturan Kepentingan (Conflict of Interest) dan Pengelolaan Laporan Harta Kekayaan Penyelenggara Negara (LHKPN).

Korupsi sebagai salah satu akibat dari buruknya tata kelola perusahaan sangat dipahami oleh PT Kereta Api Indonesia (Persero) yaitu tercermin dari beberapa program yang sudah dijalankan. Berdasarkan hasil penelitian program-program yang dijalankan tersebut yang berkaitan dengan upaya pencegahan korupsi memberikan hasil yang mengesankan yaitu selama tiga tahun terakhir tidak terjadi korupsi yang melibatkan seluruh elemen PT Kereta Api Indonesia (Persero). Upaya perbaikan dari tahun ke tahun juga tercermin dari terus meningkatnya angka Good Corporate Governance Score dari 89,011 di tahun 2016, 89,377 di tahun 2017 dan menjadi 90,025 di tahun 2018 dengan mendapatkan penghargaan sangat baik dalam assessment Good Corporate Governance 2018.

Upaya perbaikan yang membuahkan hasil tersebut merupakan sebagai bentuk perwujudan kebijakan yang efektif. Menurut La Patra, kebijakan kriminal dikatakan efektif apabila mampu mengurangi kejahatan (reducing of crime), baik dalam arti mampu melakukan pencegahan kejahatan (prevention of crime) maupun dalam arti mampu melakukan perbaikan terhadap pelaku kejahatan itu sendiri (rehabilitation of criminals) $^{23}$ Sedangkan Lawrence M. Friedman berpandangan bahwa untuk memahami hukum berlaku efektif atau tidak di dalam masyarakat, harus diperhatikan komponenkomponen sistem hukum yang berupa komponen struktural, substansi dan kultur. ${ }^{24}$

Penerapan GCG di Indonesia sangat dipengaruhi baik oleh faktor-faktor budaya maupun historis. Kedua aspek tersebut merupakan satu kesatuan yang tidak dapat dipisahakan dan

23 Muladi dan Barda Nawawi Arief, 2010. Teori-teori dan Kebijakan Pidana, Alumni, Bandung. Hal. 199.

24 Masyhur Effendi, 2004. Perkembangan Dimensi Hak Asasi Manusia, Ghalia Indonesia, Jakarta. Hal. 37. 


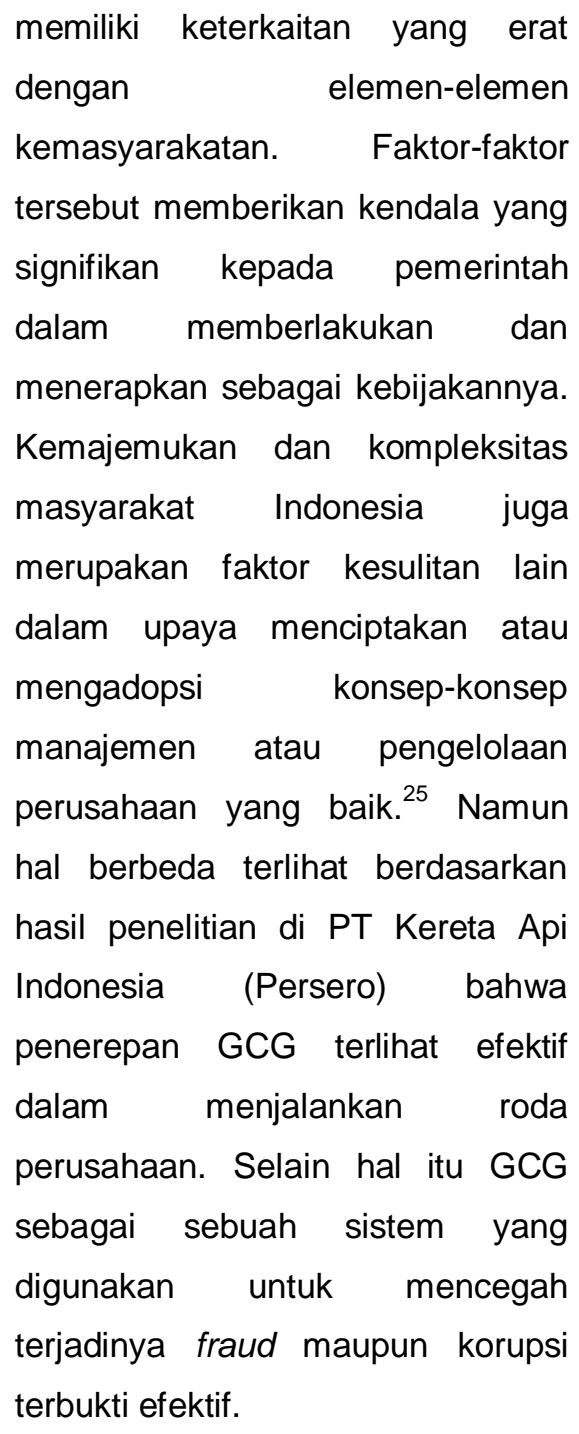

Internasional

Standarisation Organisation (ISO)

telah menyusun standar internasional ISO 37001: 2016 Anti-

Bribery Management System yang

telah diadopsi oleh Badan

Standarisasi Nasional menjadi SNI

25 Wahyono Darmabrata dan Ari Wahyudi Hertanto, 2003. Implementasi Good Corporate Governance Dalam Menyikapi Bentuk-Bentuk Penyimpangan Fiduciary Duty Direksi Dan Komisaris Perseroan Terbatas, Jurnal Hukum Bisnis, Vol. 22 (6) : 31
37001: 2016 Sistem Manajemen

Anti Penyuapan. Standar ini mensyaratkan pemenuhan klausul antipenyuapan terkait konteks organisasi, kepemimpinan, perencanaan, dukungan, operasional, evaluasi kinerja dan tindakan perbaikan. Standar ini dapat pula diterapkan dan menjadi bagian dalam program kepatuhan antikorupsi korporasi. Dengan belum diterapkannya SNI 37001: 2016 di PT Kereta Api Indonesia (Persero) praktis hanya GCG yang menjadi sebuah sistem yang dapat mencegah terjadinya tindak pidana korupsi. Untuk saat ini mungkin GCG bisa dikatakan efektif untuk mencegah korupsi maupun penyuapan di PT Kereta Api Indonesia (Persero) dan tidak ada kendala yang berarti didalam penerapannya tetapi untuk kedepannya sangat diperlukan menerapkan ISO 37001: 2016. Menerapkan ISO 37001: 2016 bukan hanya menjadikan perusahaan terhindar dari praktik suap menyuap dan korupsi namun juga menunjukkan komitmen perusahaan dalam melawan korupsi.

\section{Simpulan}

Berdasarkan pembahasan tersebut maka dapat diambil simpulan sebagai berikut: 
1) Penerapan Good Corporate Governance (GCG) dalam upaya pencegahan tindak pidana korupsi di PT Kereta Api Indonesia (Persero) berdasarkan hasil penelitian sudah efektif, hal tersebut dibuktikan dengan selama tiga tahun terakhir tidak ada tindak pidana korupsi yang melibatkan seluruh elemen perusahaan. Kesatuan sistem yang terdiri atas substance, structure dan legal culture mampu memberikan kontribusi maksimal terhadap jalannya sistem Good Corporate Governance di PT Kereta Api Indonesia (Persero) dan mampu membuat sistem tersebut berjalan efektif.

2) Kendala yang dihadapi dalam menerapkan Good Corporate Governance dapat dikatakan tidak ada dikarenakan Good Corporate Governance sudah menjadi sebuah sistem yang berjalan dan menjangkau ke seluruh elemen perusahaan untuk menciptakan tata kelola perusahaan yang lebih baik dari tahun ke tahun.

\section{DAFTAR PUSTAKA}

Adji, Indriyanto Seno 2015. Komisi Pemberantasan Korupsi dan Penegakan Hukum, Diadit Media, Jakarta.

Djaja, Ermansyah. 2010. Memberantas Korupsi Bersama Komisi Pemberantasan Korupsi, Sinar Grafika, Jakarta.

Effendi, Masyhur. 2004. Perkembangan Dimensi Hak Asasi Manusia, Ghalia Indonesia, Jakarta

Friedman, Lawrence M. 1984. American Law, W. Norton \& Co, London.

Muladi dan Barda Nawawi Arief, 2010. Teori-teori dan Kebijakan Pidana, Alumni, Bandung.

Prabowo, Muhammad Shidqon. 2004. Dasar - Dasar Good Corporate Governance, UII Press Yogyakarta, Yogyakarta.

Pranoto, Toto dkk. 2015. KAl Recipe Perjalanan Transformasi Kereta Api Indonesia, Lembaga Management Fakultas Ekonomi dan Bisnis Universitas Indonesia, Jakarta.

Rahardjo, Satjipto. 2000. IImu Hukum, PT. Citra Aditya Bakti, Bandung.

Warassih, Esmi. 2005. Pranata Hukum Sebagai Sebuah Telaah Sosiologis. PT Suryandaru Utama, Semarang.

Darmabrata, Wahyono dan Ari Wahyudi Hertanto, 2003. Implementasi Good Corporate Governance Dalam Menyikapi Bentuk-Bentuk Penyimpangan Fiduciary Duty Direksi Dan Komisaris Perseroan Terbatas, Jurnal Hukum Bisnis, Vol. 22 (6) : 3

Rasul, Sjahruddin. 2009. Penerapan Good Governance di Indonesia Dalam Upaya Pencegahan Tindak Pidana Korupsi. Mimbar Hukum. Vol. 21 (3) : 542

Susanti, Dwi Siska. Nadia Sarah, Nurindah Hilimi, 2018. Korporasi Indonesia Melawan Korupsi: Strategi Pencegahan, Integritas, Vol. 4 (2) : 224

https://news.detik.com/berita/d3879592/indeks-persepsikorupsi-2017-indonesia- 
peringkat-ke-96 diakses 30

Oktober 2018.

https://bisniskeuangan.kompas.com/rea

d/2017/04/15/070000926/korups

i.bumn.yang.makin.menggila.

diakses 30 Oktober 2018.

https://acch.kpk.go.id/id/component/bdth

emes shortcodes/?view=downlo ad\&id=5fa0dd69313917c23f775

345219cda hubungan

penerapan gcg dengan

pencegahan tindak pidana

korupsi diakses 2 September 2018.

https://putusan.mahkamahagung.go.id/p utusan/0f7ee31950caf55dd8c5a

bc3f148d541 diakses 29

November 2018.

https://putusan.mahkamahagung.go.id/p utusan/47527c03b48eafc05b84 a946d0429113 diakses 29

November 2018.

https://putusan.mahkamahagung.go.id/p utusan/400585828d95b42d53f4

6d0a8ce2f7b4 diakses 29

November 2018.

http://www.tribunnews.com/regional/201 4/06/07/mantan-kepala-daop-6pt-kai-dituntut-15-tahun-penjara. diakses 29 November 2018.

https://www.liputan6.com/news/read/305 8320/kpk-beri-warning-pt-kai-

soal-kepemilikan-aset diakses 28 Agustus 2018. 